\title{
The Death and Resurrection of Mikhail Kuzmin ${ }^{1}$
}

\section{he last volume of poetry that Mikhail Kuzmin (1872-1936) was able 1 to publish during his lifetime was The Trout Breaks through the Ice.}

A sequence of narrative and lyric poems, couched in the strikingly original surrealistic and visionary mode characteristic of this poet's later work, the book appeared in Leningrad in 1929. Where Kuzmin's first two major collections, Nets (Seti), published in 1908, and Autumnal Lakes (Osennie ozera), published in 1912, had been acclaimed and eulogized by many of the leading poets and critics of the time, The Trout Breaks through the Ice, except for two contemptuous brief notices, was passed over in silence by the Soviet press.

Still, the book had its admirers among the more discerning members of the Soviet literary community. Among them was Lidiya Chukovskaya, who confided to Anna Akhmatova in 1940 that she began to understand and to love Kuzmin only after The Trout Breaks through the Ice. ${ }^{2}$ Akhmatova, whose own early poetry betrayed Kuzmin's strong influence and who, in 1912, had asked Kuzmin to write a foreword to her first collection of verse, Evening (Vecher), inscribing the copy she gave to him "To my wonderful teacher," had, it turned out, not yet read her erstwhile teacher's last book. Chukovskaya lent it to her and one month later recorded Akhmatova's judgment. Apart from a few individual poems which she liked, Akhmatova thought the entire book derived from German Expressionist cinema and therefore lacking in originality. She found what she called the book's "obscenity" (nepristoinost') most depressing: "Kuzmin has always been homosexual in his poetry, but here he exceeds all boundaries. Before, one could not do this: Vyacheslav Ivanov might

1 Review of Sobranie stikhov, 3 vols., by Mikhail Kuzmin, ed. John E. Malmstad and Vladimir Markov (Munich: Wilhelm Fink Verlag, 1977-78). Originally published in Slavic Review 38 (1979): 92-96.

2 Lidiia Chukovskaia, Zapiski ob Anne Akhmatovoi, vol. 1 (Paris: YMCA-Press, 1976), 149. 
wince. But in the twenties, there was no longer anyone to be wary of ( $u z h e$ ne na kogo bylo ogliadyvat'sia). Perhaps Villon was able to manage this sort of thing, but as for Mikhail Alekseevich—no. It is utterly disgusting."3

For a person familiar with Kuzmin's literary career and with the Russian cultural history of the twentieth century in general, the statement is astounding. Male homosexual love, it is true, has always been a major (but by no means the only) theme in Kuzmin's poetry. Before he made his name as a poet, he acquired considerable notoriety for his autobiographical roman à thèse, Wings (Kryl'ia). Initially published in 1906 in a special issue of Vesy, one of the most prestigious literary journals of the day, and later as a separate volume that became a best seller, Wings sought to demonstrate that for people who are homosexually inclined it is better to accept their orientation, making it a part of a productive and satisfying life, than to reject and fight it. This presupposition also underlies much of Kuzmin's poetry. In this sense, his last collection, which so shocked Akhmatova, did not "exceed" any boundaries that had not already been crossed in all his other writings, beginning with the earliest. Nor is the treatment of the homosexual theme in The Trout Breaks through the Ice and Kuzmin's other collections any more or less explicit than it is, for example, in the "Calamus" section of Walt Whitman's Leaves of Grass (a book which Akhmatova much admired in Kornei Chukovsky's translation) or in the cycles Parallelement and Hombres of Paul Verlaine (surely it was Verlaine whom Akhmatova must have compared with Kuzmin, since Villon did not write on homosexual themes). Furthermore, graphic descriptions of male homosexuality are to be found in the poetry of Kuzmin's contemporary, Nikolai Klyuev, a poet who lost his freedom and eventually his life because of a poem he wrote in defense of Akhmatova (a line from which appears as an epigraph in her Poem without a Hero) and of whom she has written with warmth in her memoir of Osip Mandelstam.

Could Akhmatova have really forgotten the liberalized air of that last prerevolutionary decade, when all sorts of previously unmentionable themes-social, religious, political, and sexual-had become acceptable for literary treatment? The content of Kuzmin's love lyrics did not prevent poets as diverse as Annensky, Blok, Khlebnikov, and Tsvetaeva from

3 Ibid., 166. 
regarding him as one of the greatest poets of their time. The only major poet of that period who chose to make an issue in print of Kuzmin's homosexuality was Gumilyov, who in 1912, in his review of Autumnal Lakes (written while he was still married to Akhmatova), complimented Kuzmin on being what in the parlance of the 1970s would have been called "a spokesman for Russia's gay community."

As for Vyacheslav Ivanov-whose collection Cor ardens, published one year before Kuzmin's Nets, contained a whole section ("Eros") inspired by Ivanov's own homosexual experiences-he was surely the least likely person to have acted as Kuzmin's censor. Akhmatova may not have known Vyacheslav Ivanov's journal for 1906, where Kuzmin is described as a pioneer of the future age of sexual tolerance, ${ }^{5}$ but she must have been aware that Kuzmin had shared a residence for a number of years with Ivanov and, until her untimely death, with Ivanov's wife Lidiya ZinovievaAnnibal, a fiction writer who specialized in the theme of lesbian love.

Akhmatova's statement on Kuzmin recorded by Chukovskaya, on which I have dwelt at such length, is important in two ways. It is a key to the genesis of Akhmatova's own much-admired but often misunderstood poetic masterpiece Poem without a Hero (Poema bez geroia), which is in essence her response to Kuzmin's The Trout Breaks through the Ice and possibly also to his earlier novel Travelers by Sea and Land (Plavaiushchieputeshestvuiushchie, 1915). ${ }^{6}$ It is also indicative, in general, of the extent to which Kuzmin's role in prerevolutionary cultural life and the reception of his work by his contemporaries have been forgotten and his writings unread in postrevolutionary times.

In his essay on Kuzmin's poetry included in the edition under review, Vladimir Markov makes abundantly clear that everything printed

4 "Kuzmin occupies one of the most important places among the contemporary Russian poets. Very few are able to achieve such astounding harmoniousness of the whole [combined] with such free variety of the component parts. Furthermore, being a spokesman for the views and emotions of a whole array of people, united by a common culture, who have quite justly risen to the crest of life's wave, Kuzmin is a poet with organic roots (pochvennyi poet).” N. Gumilev, Sobranie sochinenii, vol. 4 (Washington, D.C., 1968), 307; originally in Apollon, 1912, no. 8.

5 Viacheslav Ivanov, Sobranie sochinenii, vol. 2 (Brussels, 1974), 750. Kuzmin appears in this diary under the name of "Antinous."

6 See R. D. Timenchik, V. N. Toporov, and T. V. Tsiv'ian, “Akhmatova i Kuzmin,” Russian Literature, July 1978, 213-305, for a detailed examination of the literary relationship between these two poets. 
about Kuzmin in literary histories, encyclopedias, and textbooks, from the 1930s to this day, is misleading, wrong, or incomplete. Kuzmin is often listed as an Acmeist poet, which he never was. His best or most important works are usually said to be the verse cycles Alexandrian Songs and Chimes of Love (Kuranty liubvi) and the essay "On Beautiful Clarity," which, in terms of his overall achievement, is comparable to saying that Tolstoi's most important works are Childhood and Sevastopol Stories. A wide-ranging poet whose output encompasses important historical, metaphysical, and mystical themes, as well as erotic, humorous, and light verse, Kuzmin is invariably dismissed as a frivolous hedonist who was able to write only of trivia and trifles. ${ }^{7}$ His three major collections of verse that were published in the 1920s constitute about one-half of his total poetic output by volume and represent some of his most serious and original work. Until now, however, they have remained unnoticed by literary scholars and historians.

Coming as it does after some four decades of critical and popular neglect of Kuzmin, the new edition of his complete poetry prepared by John E. Malmstad and Vladimir Markov produces the impression of a wide gate suddenly flung open onto a whole new country, partly forgotten and partly unexplored. A slow and careful reading of the seven major collections ${ }^{8}$ leaves one astounded at the scope and variety of this supposedly "graceful minor poet” (Renato Poggioli's term for Kuzmin). The unprecedented precision and intimacy with which Kuzmin's poetry of 1906-8 reflected life, its insistence on the concrete beauty of our world and the joys of here and now, which so struck his contemporaries, began alternating already in the later sections of Nets with mystical insights derived from Kuzmin's study of Gnosticism as well as from his Old Believer heritage. This alternation continued in his later work, and its persistence makes mincemeat out of all critical attempts to fit Kuzmin into either the Acmeist or the Symbolist mold. Aleksandr Blok was neither whimsical nor paradoxical when he

7 A typical example of this kind of uninformed treatment of Kuzmin is found in Renato Poggioli, The Poets of Russia 1890-1930 (Cambridge, MA, 1960).

8 Kuzmin's major collections are Nets, Autumnal Lakes, Clay Doves (Glinianye golubki, ca. 1915), The Guide (Vozhatyi, 1918), Otherworldly Evenings (Nezdeshnie vechera, 1923), Parabolas (Paraboly, 1923), and The Trout Breaks through the Ice. The edition under review also contains six lesser collections of verse published by Kuzmin, his verse play for puppets, Tuesday at Mary's (Vtornik Meri, 1921), and, in vol. 3, a large number of previously uncollected or unpublished poems. 
saw the roots of Kuzmin's art in "the awakening of the Russian Schism, in the dark religious forebodings of fifteenth-century Russia, in the memory of the trans-Volga startsy (elders) who would come out of obscure marsh bogs into squat, smoke-filled peasant huts."

An aspect of Kuzmin not found in other poets of his time is his habit of organizing his lyric poetry into cycles with easily discernible plots, which results in a hybrid genre that combines the features of the traditional lyric with those of a narrative poema. This is the form in which much of his autobiographical poetry is couched. It culminates in the remarkable novellas in verse of The Trout Breaks through the Ice, which belong among the finest examples of Russian twentieth-century narrative poetry. Kuzmin is a master of a variety of larger narrative verse structures, such as the remarkably beautiful Cavalier (Vsadnik) (included in Autumnal Lakes), which was surely the point of departure of Marina Tsvetaeva's epic poems On a Red Steed and Tsar-Maiden; the extended ode in free verse, "The Hostile Sea" ("Vrazhdebnoe more"), written in 1917 and dedicated to Vladimir Mayakovsky, which mingled Homeric themes with the mood of Russian revolution; or the visionary and surrealistic longer poems of the last two collections.

The Malmstad-Markov three-volume edition shows us the full stature of the poet Kuzmin, with all his stylistic and metrical virtuosity, verbal elegance, cultural range, and spiritual depth. But the two editors have done a great deal more than assemble the corpus of Kuzmin's poetry. John E. Malmstad's "Mikhail Kuzmin: A Chronicle of His Life and Times" occupies three hundred twelve pages in the third volume. It is not an introductory essay, but rather a substantial, full-scale, critical biography which also happens to be one of the very finest biographies of a twentieth-century Russian poet that we have. Kuzmin was a central figure in the literary life of his day as well as a friend or associate of many important writers and poets. He was also deeply involved in the worlds of music, art, and the theater. Among the dramatis personae of his biography were his school friend Georgy Chicherin (the future famous diplomat), Blok and Diaghilev, Meyerhold and Komissarzhevskaya, and the painters Sapunov and Sudeikin. It was an exciting and eventful life, and John E. Malmstad reconstructs it with sympathy and erudition. Its bilingual format (the nu-

9 Aleksandr Blok, Sobranie sochinenii (Moscow and Leningrad, 1960-63), 5:183. 
merous citations of Russian texts are left untranslated) limits the number of potential readers of this excellent biography. It would be a shame if it were not eventually published as a separate book and thus made available to the general reading public. ${ }^{10}$

Every bit as impressive is Vladimir Markov's one-hundred-four-page critical appreciation of Kuzmin's poetry, "Poeziia Mikhaila Kuzmina" (also in the third volume). Markov has set himself the difficult and usually thankless task of demonstrating that a literary figure whom most critics have come to regard as peripheral or minor is actually an unfairly neglected major poet. His assertion and demonstration of the value of Kuzmin's poetry is a model of lucid and logical literary argument. The two editors provided the entire corpus with detailed annotations, which display an admirable command of the diverse cultural spheres reflected in Kuzmin's poetry.

At a ceremony in honor of Kuzmin's birthday in 1920, the speakers included, inter alios, Aleksandr Blok, Nikolai Gumilyov, Boris Eikhenbaum, and Viktor Shklovsky. In his speech, Blok expressed a wish that conditions be created in the future such that a literary artist as unique as Kuzmin would have the right "to remain himself." ${ }^{11}$ We know that things did not turn out as Blok had wished, and that, after Soviet culture took the form it did, the mere fact of Kuzmin's sexual orientation contributed to reducing an admired poet to a pariah and a nonperson, so that even a poet of Akhmatova's stature and independence was able to turn against him with puritanical vindictiveness and depict him in Poem without a Hero as an evil demon responsible for bringing on cultural decline. ${ }^{12}$ The new publication of his complete poetry, combined with the important critical contributions by John E. Malmstad and Vladimir Markov, should help restore Kuzmin to his rightful place among the foremost Russian poets of the twentieth century.

10 Malmstad later collaborated with a Kuzmin specialist in Moscow on a revision of his original text: John E. Malmstad and Nikolay Bogomolov, Mikhail Kuzmin: A Life in Art (Cambridge, MA: Harvard University Press, 1999).-Ed.

11 Blok, Sobranie sochinenii, 6:440.

12 The authors of an otherwise fine and informative study, "Akhmatova i Kuzmin" (see note 6 above), jeopardize their scholarly probity by their occasional moralizing attempts to justify Akhmatova's later aversion to Kuzmin by referring to the latter's supposed misogyny and amorality. Their strictures, when placed next to John E. Malmstad's informed and sympathetic biography, make instructive reading. 
In later years, SK wrote frequently about Kuzmin for the gay press. His review of Michael Green's English translation of selected prose writings (including Wings) and poetry by Kuzmin is of particular interest and is included in Simon Karlinsky, "Gay Life before the Soviets: Revisionism Revised," Advocate, 1 April 1982, 31-34. See also his entry on Kuzmin in Gay Histories and Cultures: An Encyclopedia, ed. George E. Haggerty (New York: Garland Publishing, 2000), 526-27.

Among SK's translations of Russian poetry is the following love lyric by Kuzmin:

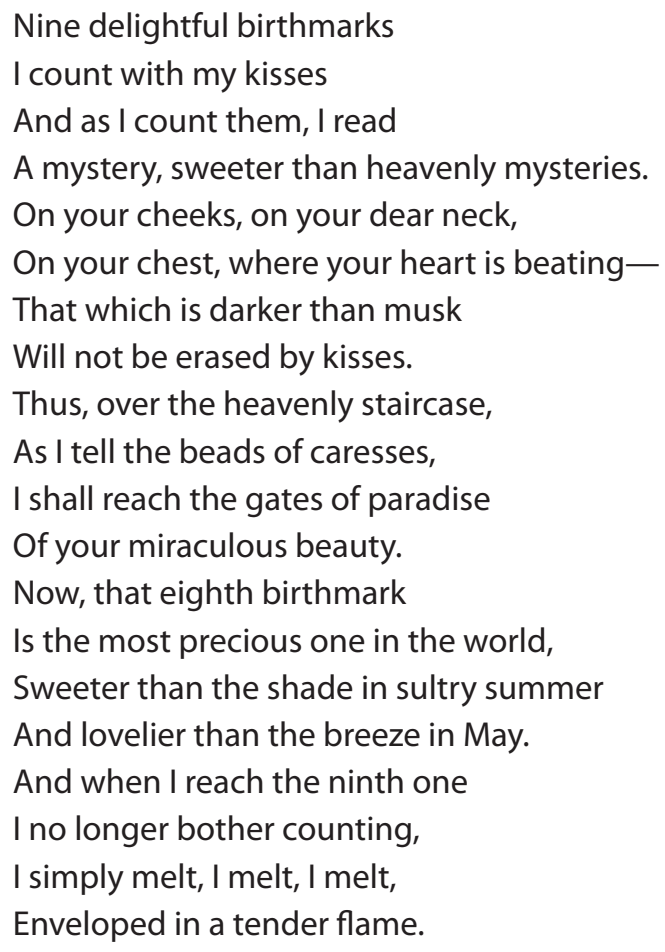

In the late 1970s and the 1980s SK took up the cause of a young contemporary poet who was strongly influenced by Russia's homosexual poets of the

13 Simon Karlinsky, trans., "Three Russian Poets," in Gay Roots: Twenty Years of Gay Sunshine, ed. Winston Leyland (San Francisco: Gay Sunshine Press, 1991), 652. 
early twentieth century such as Mikhail Kuzmin and Nikolai Klyuev. Gennady Trifonov (1945-2011) was unabashedly gay and delineated his homosexual experiences in his lyric poetry. It is hardly surprising that he was not allowed to publish and, indeed, in 1976 was sentenced to four years of incarceration for homosexuality (muzhelozhestvo, article 121 of the Soviet criminal code), hooliganism, and dissident activities. SK's several articles about this young man and translations of his poetry were important in drawing attention in the West to Trifonov's plight. Among them were Simon Karlinsky, "The Case of Gennady Trifonov," Christopher Street, January 1979, 65-66; Simon Karlinsky, "The Case of Gennady Trifonov," New York Review of Books, 10 April 1986, 44; and Simon Karlinsky, "The Soviet Union vs. Gennady Trifonov," Advocate, 19 August 1986, 42-49. Upon release from prison in 1980, Trifonov was forced to eke out an existence for himself and his mother by manual labor and lived in fear of rearrest. By 1998, however, he was being published in a few journals in Leningrad and was soon allowed to travel abroad. His improved situation undoubtedly was at least partially caused by the pressure of international opinion, in which SK played no small role. 